18-20 June, 2021

\title{
Methods of Working with the Theme of Shoah in the Context of Institutional Education
}

\author{
Milan Mašát ${ }^{1}$ \\ Palacký University Olomouc, Faculty of Education, The Department of Czech Language and Literature, Žižkovo \\ náměsí 5, 77140 Olomouc, Czech Republic
}

\begin{abstract}
.
In this paper, we present selected methods for working with the theme of Shoah with a focus on Literary Education at the lower-secondary school. After a theoretical introduction, in which we briefly summarize the importance of the Shoah issue for citizens living in society in the twenty-first century, we present in some detail the presentation of selected methods for acquainting students with the defined phenomenon with emphasis on education at the second stage of basic institutional education. We present in more detail The Survivors' Heritage, The Historical Approach, The Multi-Level Approach, An Interdisciplinary Approach and The Intercultural/Antiracist Approach. We also mention the approach marginally Did the Shoah Really Happen? Evaluating Sources and Evidence. In the article, we mean by the concept of the Shoah, experiencing the events of one line of the Second World War from the position of Jews, and at the same time we perceive it as a synonym for the term Holocaust.
\end{abstract}

Keywords: Shoah, Holocaust, method, approach, student, teaching

\section{Introduction}

We are guided to choose the topic of the paper mainly by the constant topicality of the Shoah phenomenon in contemporary society: especially by the degree of intolerance, racism, xenophobia, and anti-Semitism. (compare Abrams, 1997) This fact is underlined by the fact that the Parliament of the Czech Republic has recently adopted a resolution based on the definition of anti-Semitism according to the International Holocaust Remembrance Alliance (IHRA; 2016, p. not specified) ${ }^{1}$ : "Antisemitism is a certain perception of Jews, which may be expressed as hatred toward Jews. Rhetorical and physical manifestations of antisemitism are directed toward Jewish or non-Jewish individuals and/or their property, toward Jewish community institutions and religious facilities." (Mašát, 2019) Holý et al. (2011, p. 6) state that the issue of the Shoah "contributes to the maintenance and restoration of historical and national memory. At a time of oblivion, which controls a large part of Czech and, in fact, European society, and which may result in indifference or even denial of the Holocaust, this is relevant. There are no perfect legal or institutional mechanisms to prevent new genocides and totalitarianisms once and for all. We must therefore rely on basic moral principles and an awareness of this historical and cultural memory." Holý (2016, p. 573) emphasizes the need to 


\section{8-20 June, 2021}

present the events of one line of World War II through various media: "The Holocaust as a historical event, however we perceive and evaluate it, has become a turning point in the development of modern European civilization. It is the subject of an examination of History and other humanities, but also a challenge for literature and other media, especially film." As part of a lecture given at the conference European Holocaust Research Infrastructure ${ }^{2}$ stated Pohl (2020) that the issue has a dual nature:

\section{1) the Holocaust as a scientific problem and}

\section{2) the Holocaust as part of cultural memory.}

Pohl (2020, p. 133) says "that the role of Holocaust studies for societies is very distinct has to cope with different contexts, though its main asset should remain a methodological and conceptual rigour as well as an openness to new and even more unpleasant findings. It can deliver the basis for societal discourses that transcend rituals of memorialisation (...). Holocaust research can also identify and evaluate examples of help and rescue, of international intervention. Finally, the most important pursuit for our understanding of the Holocaust and the lessons to be drawn from it should be an apprehension and analysis of the destruction of democratic order or of any order based on a law-abiding state."

The rise of anti-Jewish sentiment in European society can be demonstrated by research Antisemitic Violence in Europe, 2005-2015. Exposure and Perpetrators in France, UK, Germany, Sweden, Norway, Denmark, and Russia (Due Enstad, 2017), which examined the development of anti-Jewish sentiments in seven selected European countries ${ }^{3}$. A total of 16 500 respondents took part in the survey, defining themselves as Jews. A total of $85 \%$ of them stated that they perceived the rise of anti-Semitism as a serious problem. (Mašát, 2019)

We are of the opinion that literary texts represent a suitable means for presenting the issue of the Shoah to students at all levels of institutional education. In artistic narratives, recipients are presented with positive and negative patterns of behaviour. Homolová notes (cited by Ortnerová, 1995 in Gejgušová et al., 2012, p. 47): "Children like to identify with the heroes of the stories and enthusiastically accept the offered ideas and suggestions for solving problems of identification with the reader are then used pedagogically to form new habits and patterns of behaviour in children." (compare Giambastiani, 2020) It is important that the art literature that students are introduced to is primarily intentional (this means that this area of literature is intended directly for children and youth). We assume that this area of literature is adapted by its composition to the specific age of readers, and therefore the impact of reading in the field of acquiring axiological values or patterns of behaviour may be greater based on reading literature for children and youth by a defined circle of recipients.

Every teacher who decides to present the subject of the Shoah to the pupils is faced with the decision of which method to present the phenomenon defined to them ${ }^{4}$.

\footnotetext{
${ }^{2}$ See https://www.ehri-project.eu/final-conference-second-phase-ehri-project.

${ }^{3}$ France, Great Britain, Germany, Sweden, Norway, Denmark, Russia. See https://www.hlsenteret.no/aktuelt/publikasjoner/digitale-hefter/antisemittisk-vold-i-europa_engelsk_endeligversjon.pdf.
}

${ }^{4}$ Rich provides an overview of the methods used in the presentation of Holocaust/Shoah themes in the essay 


\section{8-20 June, 2021}

\section{On Specific Methods of Presenting Shoah Events to Students}

A certain way in which teachers can acquaint pupils with a given phenomenon was suggested by experts in a seminar Teaching about the Holocaust, which took place in Vilnius in Lithuania in 2000. At the seminar, it was proposed to divide the methods of teaching about the Holocaust into:

- the so-called traditional method, which "might involve the use of pictures, probably from a used textbook" (Grech, 2000, p. 15) and

- $\quad$ other methods, which "often involve new technologies: CD ROMs, the Internet, movies and documentaries, interviews with survivors." (Grech, 2000, p. 15)

The following theses were agreed at the Lithuanian seminar:

- "We don't need to follow a single method, nor should we."

- "Children learn in different ways, so it is necessary to use different methods in teaching."

- "The result of teaching must be that students learn something. Therefore, they must be motivated. That is why it is necessary to use more demanding and stimulating teaching methods."

- "If we follow one method, the hours will be boring."

- "Traditional methods (such as narrative) continue to be an important part of teaching History. Students can engage and motivate these methods."

- "Teaching aids, whatever they may be, can never replace teachers. But the teacher must be a professional. Not only does he understand the curriculum, but he must also be well trained in the use of various teaching skills." (Grech, 2000, p. 16)

Among the targeted teaching methods (certain teaching skills) Grech (2000, p. 15) includes:

- "ability to communicate clearly about objectives";

- "the ability to choose the most appropriate and effective teaching method in a given situation";

• "good voice work";

- "dramatization";

- "the ability to empathize with what is said and presented";

- "eye contact";

- "the body language";

• "questioning technique". 


\section{8-20 June, 2021}

Within the Anglo-American methodological approach to the given issue, the so-called integration approach in the field of mediation of a defined object is currently developing dynamically. According to Tinberg \& Weisberger (2014) this approach can increase students' mastery of critical thinking and enhance their perception of diversity and morality.

Four possible approaches to mitigate the differences between students' previous experiences and the empirics presented to them are presented by Martin (2007, pp. 493-503):

- "Student presentations on Holocaust survivors.

- Documentary film about ghettos and camps.

- Student debates: Why did this happen?

- Did the Shoah really happen? Evaluation of sources and evidence".

At the final conference IHRA Education Research Project ${ }^{5}$ held in Lucerne in February 2016, two basic objectives of Shoah education were defined:

(1) "the two mains (but partly contradictory) objectives necessary are to remind victims";

(2) "to prevent genocide, which implies certain conclusions for current crises, such as the Syrian civil war and the refugee situation." (von Borries, 2017, p. 425)

As the most important point in the defined area, the experts identified the need for everyday education (learning) on the issue, which, however, must be consistently distinguished from intervention through teaching based on traditional, best practices. (von Borries, 2017)

Imber (2013) defines the main models of acquainting pupils and students with the subject of the Shoah (Holocaust):

The Survivors' Heritage is a model without which, according to Imber, the subject of the Shoah cannot be presented. Authentic statements are the most faithful mediator between a historical event, the people involved and the recipients. Holocaust survivors play a pivotal role in the history of the Holocaust, in shaping its memory and in commemorating this event, and in education.

As part of the activities of the $i$ Witness platform $^{6}$ a research survey was set up based on interviews with five teachers who integrate survivors' testimonies into their teaching. Video recordings are freely available on the institution's website. The core of the interview was the question of the development of empathy of students with survivors based on viewing records. The findings suggest that the implementation of survivors' testimonies into teaching develops students' empathy and understanding of the historical period. Teachers believe that testimonies humanize the content of the Holocaust, which in turn leads to the development and deepening of students' relationship with survivors. (Haas, 2019) The testimony of survivors may be expressed in other ways than by giving a verbal statement.

5 See https://www.holocaustremembrance.com/news-archive/ihra-project-recommendations-teaching-andlearning-about-holocaust. 


\section{8-20 June, 2021}

One of these ways - photography - is in the essay Photographing Survival: Survivor Photographs of, and at, Auschwitz (2020) deals Cole. The core of the essay is an examination of photographs taken by survivors during post-war visits to Auschwitz. The authors supplement the photo with their own titles. The visual documentation is largely different, but as a collection it contrasts sharply with photographs taken by tourists visiting Auschwitz: in the centre of the photographs taken by tourists there are empty (emptied) spaces, the core of the survivors' visual documentation are portraits or self-portraits. (Cole, 2020)

We believe that the potential of memoir literature on a given topic is not sufficiently used in the teaching of the Shoah in primary schools. We are of the opinion that a significant degree of authenticity in several examples of children's written records can facilitate the understanding of a defined event by recipients (not only) in primary schools.

Carrol (1999) comments on certain limitations of this approach, arguing that survivors of the Nazi extermination machinery do not want to testify out of their belief in their own inferiority, mainly because of the feeling of incomplete news stemming from the fact that they have survived, meaning that they did not know the "complete" Nazi tyranny. With The Survivors' Heritage corresponds The Historical Approach in which centre of which stands a view of the Holocaust from a history perspective. (Moisan et al., 2015) This approach uses the historical context in the presentation of one line of events of World War II and should lead to a deeper study of the issue and should include the context of history as well as reflecting on the concepts of democracy in opposition to totalitarianism and Nazi ideology, the concept of propaganda, social conformity, international relations, opposition groups (minorities) and their actions as victims.

The Multi-Level Approach is based on the premise that the transmission of ethical values should begin at a very early age. (Imber, 2013)

Moisan et al. (2015) define The Ethical Approach which should lead students to replicas of the questions. This teaching aims to stimulate the reflection of values such as tolerance, freedom, social order and its observance, justice, ambiguity of humanity.

The Human Rights Education related to the ethical aspects of events connoting the Shoah. This approach views the issue through power, rights, and legislation as well as human dignity. (Moisan et al., 2015)

An Interdisciplinary Approach assumes that the presentation of a story of a specific person opens the possibility of knowing the events of the Shoah from various angles, which include an understanding of the human being and the human spirit. According to Imber (2013), even these metaphysical aspects should be part of the teaching about the Shoah. The interdisciplinary approach includes art, literature, philosophy, and other disciplines. By combining these disciplines, it is then possible to achieve an understanding of the human soul, which cannot be achieved by studying historical documents alone. Hallama (2020, p. 19) states this approach in the context of the study of history: "In the era of interdisciplinarity and transdisciplinary, there are efforts to apply the ideas of sociology and anthropology more significantly in the historical memory studies." We believe that most literary monuments dealing with the Jewish line of World War II and having a certain degree of authenticity combine the mentioned aspects and through the reception of these written monuments we can reach a state of at least elementary holistic knowledge of a person experiencing persecution with all consequences. Some correspondence between this Imber postulated approach can be 


\section{8-20 June, 2021}

found in the formulation The Intercultural/Antiracist Approach. Teachers who have adopted this approach try to explain to students what racism is and how it manifests itself. Students who have taken courses in which this approach has been used will more easily recognize racism in its infancy. (Moisan et al., 2015; compare Salmons, 2003)

Martin (2007) lists the Shoah as a special category of methods of presentation Documentary Film on the Ghettos and the Camps Martin (2007, pp. 496-497) names for example Schindler's List, which "can be used effectively in the classroom."

Martin (2007) further states the method Student Debates: Why Did This Happen? Students should argue appropriately in the debate.

The last approach Martin takes is Did the Shoah Really Happen? Evaluating Sources and Evidence within which students should be confronted with opinions, in the centre of which there is information that the events of the Shoah did not take place. This method is directed against the views of Holocaust deniers, who claim that the conspiracy of world Jewry". "Their aim is to get as many listeners as possible for their ideas, to whom they would present their scientific evidence, i.e. distorted historical facts, and thus help to uncover the world's lies about the Holocaust. Unfortunately, the ancient tendency to seek a Jewish conspiracy for the country’s problems is still deeply rooted in society."8 (Ševčíková, 2013, p. 182)

Kryl et al. (2011, p. 237) add that "Holocaust deniers are rooted in the opinion of a group of historians of the first half of the 20th century who tried to reinterpret the causes and background of the First and Second World Wars. These historians, who called themselves revisionists, relativized the role of Germany, and instead emphasized the mistakes and guilt of the treaty powers in World War I and the Allies in World War II. In the event of World War II, they equated some Allied coalition practices (bombing Germany or expelling Germans from liberated territories) with Nazi crimes. Shortly after the end of World War II, the French fascist Maurice Bardèche (1907-1998) was the first to spice up these views on Holocaust denial. According to Lindquist (2010), many experts define the rolling methods of mediating the subject of the Shoah to younger school-age pupils. Many teachers think that the Shoah should be taught in the first stage of primary schools and in kindergartens, because teaching for tolerance based on the Holocaust is very appropriate in this period. Due to the focus of the contribution, we do not consider it necessary to present such oriented views here (see, for example, Hersh, 2016; Kraft, 2014 or Unterman, 2016).

\footnotetext{
${ }^{7}$ Pešková $(2015$, p. 23) on Holocaust deniers claims that these "do not deny that many Jews lost their lives during the war, but it was caused by natural hardship during the war, but they were definitely not killed. The deniers further claim that the Jews are not victims and use the image of the suffering nation to obtain large sums of money as compensation. The basic claim of the deniers is that the Jews are not victims, but vice versa." A worksheet for high school students was created on the issue of Holocaust denial. ( see Lipstadt, 2006) Students are led by methods of critical thinking to consider arguments and counterarguments in the field of the Holocaust, they are introduced to the most stubborn deniers or are introduced to court proceedings (such as Nuremberg or Auschwitz).

${ }^{8}$ Compare: "If we look even further into the 1950 s, we realize that the history of Holocaust denial and
} 


\section{8-20 June, 2021}

\section{Conclusion}

In the article, we dealt with methods of presenting the subject of the Shoah to students. We mentioned, for example, the The Survivors' Heritage which consists in passing on the life experience of Holocaust survivors to future generations, either through interviews or through literary recollections - this approach is, in our view, more applicable to real teaching. The given model can also be applied in the testimony of the descendants of the survivors of the Nazi extermination machinery from the second or third generation. The use of the model a priori presupposes as a starting point the testimony of Jewish people. We believe that it is very important to enrich this model with testimonies from Germans, Poles, and the like. In our opinion, teaching in which more perspectives on a given issue will be implemented has the potential to develop in students critical thinking, argumentation techniques or the ability to look at problems (of the contemporary world) comprehensively.

The Historical Approach is based on the thesis that students learn about history through Literary Education. This approach, at the level of a certain amount of necessary facts, which primary school pupils should acquire, represents a shift from the transmissive transfer of knowledge to active pupil involvement in the search for connections between artistic narration and real historical events.

The Multi-Level Approach is based on the thesis that the building of desirable axiological values of pupils, the acquisition of ethical norms or the perception of democracy as a value should begin at the youngest possible age. It should be a matter of course to adapt the teaching tool (in our case, art stories) to the age of the pupils.

An Interdisciplinary Approach is based on the presentation of Shoah events through the life destiny of a person. Diaries of Jewish children and adolescents seem to be especially suitable for teaching at primary school - in the connotation with their anchoring in the historical and social context, it can lead to looking at the issue in different ways (from different angles). We see the main benefit of this approach in the prevention of flattening the view of the Shoah only as an effort to exterminate Jews.

\section{Acknowledgment}

This paper is an output of the science project IGA_PdF_2021_001_Multilateral Representation of Shoah Events in the Literature provided by Palacký University in Olomouc.

\section{References}

Abrams, I., M. (1997). Elie Wiesel - Nobel Lecture. Available at http://www.nobelprize.org/.

Carrol, D. (1999). The Limits of Representation and the Right to Fiction: Shame, Literature, and the Memory of the Shoah. L'Esprit Créateur, 39(4), 68-79. https://doi.org/10.1353/esp.2010.0045.

Cole, T. (2020). Photographing Survival: Survivor Photographs of, and at, Auschwitz. In Aarons V., \& Lassner P. (Eds.), The Palgrave Handbook of Holocaust Literature and Culture (pp. 633-648). Palgrave Macmillan: Cham. https://doi.org/10.1007/978-3-03033428-4_34. 


\section{8-20 June, 2021}

Due Enstad, J. (2017). Antisemitic Violence in Europe, 2005-2015. Exposure and Perpetrators in France, UK, Germany, Sweden, Denmark, and Russia. Oslo: University of Oslo.

Giambastiani, V. (2020). Children's Literature and the Holocaust. Genealogy, 4(1), 1-9. https://doi.org/10.3390/genealogy4010024.

Grech, L. (2000). Teaching about the Holocaust. Strasbourg: Council for Cultural Cooperation.

Haas, B., J. (2019). Bearing Witness: Teacher Perspectives on Developing Empathy through Holocaust Survivor Testimony. The Social Studies, 111(2), 86-103. https://doi.org/10.1080/00377996.2019.1693949.

Hallama, P. (2020). Národní hrdinové - židovské oběti. Holokaust v české kulturní paměti. Praha: NLN.

Hersh, E. (2016). How Can We Teach About the Holocaust to Seven to Ten Year Olds? (Bachelor thesis). Available at https://digitalcommons.butler.edu/ugtheses/331.

Homolová, K. (2012). (Staro)nově k počátkům dětského čtenářství. In Gejgušová, I. et al. (Eds.), Současná literatura pro děti a její vliv na rozvoj čtenářství (pp. 39-59). Přerov: Městská knihovna v Přerově, p. o.

Holý, J. (2016). Šoa ve fikční próze do konce šedesátých let. In Holý, J. (Ed.)., Cizí i blízcí. Židé, literatura, kultura věeských zemích ve 20. století (pp. 573-600). Praha: Akropolis.

Holý, J. et al. (2011). Šoa v české literatuře a v kulturní paměti. Praha: Akropolis.

Hř́bková, H. (2013). Od pochybování $k$ popírání holocaustu - mystifikace druhé a třetí generace; meze svobody. Praha: Centrum pro studium holokaustu a židovské literatury.

Imber, S. (2013). How We Approach Teaching About the Shoah. Available at https://www.yadvashem.org/articles/general/pedagogical-philosophy.html.

Kraft, D. (2014). How Young Is Too Young to Teach My Child About the Holocaust? Available at https://www.haaretz.com/jewish/teaching-kids-about-the-holocaust-1.5246405.

Kryl, M. et al. (2011). Rasismus, antisemitismus, holocaust. Ústí nad Labem: Filozofická fakulta Univerzity Jana Evangelisty Purkyně v Ústí nad Labem.

Lindquist, D., H. (2010). Complicating Issues in Holocaust Education. Journal of Social Studies Research, 34(1), 77-93. Available at https://eric.ed.gov/?id=EJ887319.

Lipstadt, D., E. (2006). Popírání holocaustu. Sílici útok na pravdu a pamět'. Praha: Památník Terezín.

Martin, K., C. (2007). Teaching the Shoah: Four Approaches That Draw Students In. The History teacher, 40(4), 493-502. https://doi.org/10.2307/30037046.

Mašát, M. (2019). To Implement the Theme of Shoah in the Teaching of Literary Education from the Point of View of Teachers. Paidagogos, 1(3), 35-61. Available at http://www.paidagogos.net/issues/2019/1/article.php?id=3.

Moisan, S. et al. (2015). Holocaust Education in Quebec: Teacher's Positioning and Practices. McGill Journal of Education, 50(2-3), 247-268. https://doi.org/10.7202/1036432ar. 


\section{8-20 June, 2021}

Ortnerová, G. (1995). Pohádky radí nejmenším. Praha: Knižní klub.

Pešková, L. (2015). Holocaust Denial in the Work of David Irwing (Bachelor thesis).

Available at

https://dspace.tul.cz/bitstream/handle/15240/25717/BP.lucie.peskova.pdf?sequence=-

$1 \&$ isAllowed $=\mathrm{y}$.

Pohl, D. (2020). Holocaust Studies in Our Societies. S. I. M. O. N. SHOAH: INTERVENTION. METHODS. DOCUMENTATION, 7(1), 133-141. https://doi.org/10.23777/SN.0120/SWL_DPOH01.

Rich, J. (2020). Understanding and Teaching Holocaust Education Holocaust Education in Primary Schools in the Twenty-First Century: Current Practices, Potentials, and Ways Forward Contemporary Debates in Holocaust Education Essential Issues of Holocaust Education: Fundamental Issues and Approaches. Journal of Jewish Education, 86(1), 120124. https://doi.org/10.1080/15244113.2020.1707638.

Salmons, P. (2003). Teaching or Preaching? The Holocaust and intercultural education in the UK. Intercultural Education, 14(2), 139-149. https://doi.org/10.1080/14675980304568.

Ševčíková, E. (2013). Holocaust Denial in the Czech Republic. Acta Universitatis Carolinae Iuridica, 59(2013), 179-192.

Tinberg, H., \& Weisberger, R. (2014). Teaching, Learning and the Holocaust. An Integrative Approach. Bloomington: Indiana University Press.

Unterman, S., M. (2016). How Do You Teach the Holocaust to Kids Who've Never Heard of It? Available at https://forward.com/culture/348921/how-do-you-teach-the-holocaust-tokids-whove-never-heard-of-it/.

von Borries, B. (2017). Learning and teaching about the Shoah: retrospect and prospect. Holocaust Studies. A Journal of Culture and History, 23(3), 425-440. https://doi.org/10.1080/17504902.2017.1298348.

Website of EHRI: European Holocaust Research Infrastructure: https://www.ehriproject.eu/final-conference-second-phase-ehri-project.

Website of International Holocaust Remembrance Alliance (IHRA): https://www.holocaustremembrance.com.

Website of iWitness: https://iwitness.usc.edu/SFI/. 